\title{
ОСОБЛИВОСТІ МЕХАНІЗМУ УПРАВЛІННЯ
} МАРКЕТИНГОВОЮ ДІЯЛЬНІСТЮ ПІДПРИЄМСТВА ОБОРОННОЇ ГАЛУЗІ

\section{FEATURES OF THE MECHANISM OF MANAGEMENT OF MARKETING ACTIVITY OF THE ENTERPRISE OF DEFENSE BRANCH}

УДК: 339.138:355/359

DOI: https://doi.org/10.32843/infrastruct51-38

\author{
Шумкова О.В. \\ к.е.н., доцент, \\ доцент кафедри маркетингу \\ та логістики \\ Сумський національний \\ аграрний університет \\ Швець Є.М. \\ магістрант \\ Сумський національний \\ аграрний університет
}

\section{Shumkova Olena \\ Sumy National Agrarian University \\ Shvets Yevhenia}

Sumy National Agrarian University

\begin{abstract}
Статтю присвячено питанням вивчення головних особливостей механізму управління маркетинговою діяльністю підприємства оборонної галузі. Визначено, що управління маркетинговою діяльністю підприємства слід розглядати як сукупність процесів, які включають у себе аналіз, планування, реалізацію та контроль над процесом реалізації заходів, які необхідні для встановлення, зміцнення і підтримки прочесів обміну на цільових ринках для досягнення відповідної мети підприємства. Охарактеризовано основні елементи механізму управління маркетинговою діяльністю підприємства оборонної галузі. На прикладі Державного підприємства «Конотопський авіаремонтний завод «Авіакон» проведено аналіз результативності та ефективності представленого механізму управління маркетинговою діяльністю з використанням показників для оцінки основних елементів комплексу маркетингу - товарів та послуг, ціни, розподілу та стимулювання.

Ключові слова: маркетингова діяльність, управління, управління маркетинговою діяльністю, механізм, оборонна галузь.
\end{abstract}

Статья посвящена вопросам изучения главных особенностей механизма управле- ния маркетинговой деятельностью предприятия оборонной отрасли. Определено, что управление маркетинговой деятельностью предприятия следует рассматривать как совокупность процессов, которые включают в себя анализ, планирование, реализацию и контроль над процессом реализации мер, необходимых для установления, укрепления и поддержания процессов обмена на челевых рынках для достижения соответствующей цели предприятия. Охарактеризованы основные элементы механизма управления маркетинговой деятельностью предприятия оборонной отрасли. На примере Государственного предприятия «Конотопский авиаремонтный завод «Авиакон» проведен анализ результативности и эфрорективности представленного механизма управления маркетинговой деятельностью с использованием показателей для оценки основных элементов комплекса маркетинга - товаров и услуг, цены, распределения и стимулирования.

Ключевые слова: маркетинговая деятельность, управление, управление маркетинговой деятельностью, механизм, оборонная отрасль.

The article is devoted to the study of the main features of the mechanism of management of marketing activities of the enterprise of defense branch. The authors note that Ukraine is a world leader in the production of navigation devices, homing heads for surface-to-air missiles, radio control stations, sound-metric artillery reconnaissance systems, complex control systems, radio communication equipment, radio and electronic warfare, aviation and missile systems aiming. Ukraine has a well-developed electro-optical industry. It is determined that the management of marketing activities of the enterprise should be considered as a set of processes that include analysis, planning, realization and control of the implementation of measures which are necessary to establish, to strengthen and to maintain exchange processes in target markets. All these activities will help the enterprise to achieve the main goal of its work. The purpose of managing the marketing activities of the enterprise is to ensure a high level of quality of the management process, which will effectively implement the marketing activities of the enterprise in the short and long term. The article describes the main elements of the mechanism of management of marketing activities of the enterprise of defense branch. On the example of the State Enterprise «Konotop Aircraft Repair Plant «Aviacon» the authors provided the analysis of the effectiveness and efficiency of the presented mechanism for managing the marketing activities using indicators to assess the main elements of the marketing complex, such as products and services, price, place and promotion. Management of marketing activities of the enterprise and the mechanism of its implementation should be aimed at the effectiveness of the activities of the enterprise and ensure timely detection and reduction or overcoming of marketing risks, clear definition of marketing and enterprise activities, accurate planning of all marketing activities, effective control of marketing management activities and to carry out timely operational intervention in marketing processes under the influence of changes in the factors of internal and external marketing environment.

Key words: marketing activity, management, management of marketing activity, mechanism, defense branch.

Постановка проблеми. Провадження діяльності підприємства у сучасних умовах господарювання передбачає постійний моніторинг змін у споживчих цінностях та чинників маркетингового середовища й оперативне реагування на них. Успіх підприємств за таких обставин залежить від ефективного управління не лише діяльністю підприємства у цілому, а й від ефективності управління маркетинговою діяльністю зокрема. Формування ефективного механізму процесу управління маркетинговою діяльністю підприємства $є$ одним із головних завдань під час провадження діяльності підприємства.

Аналіз останніх досліджень і публікацій. Сьогодні проблематика управління маркетинговою діяльністю та аналіз проблем удосконалення маркетингової діяльності посідають одне з перших місць у дослідженнях провідних вітчизняних та закордонних економістів та вчених, таких як Г. Армстронг, Дж. Еванс, Б. Карлофрф, Ф. Котлер, Л.В. Балабанова, А.В. Войчак, С.С. Гаркавенко, В.Г. Герасимчук, О.Л Каніщенко, В.Я. Кардаш, Є.В. Крикавський, Н.В. Куденко, А.О. Старостіна, І.Л. Решетнікова.

Постановка завдання. Метою дослідження $\epsilon$ вивчення особливостей механізму управління маркетинговою діяльністю підприємства оборонної галузі.

Виклад основного матеріалу дослідження. Сучасна структура оборонної промисловості 
України за напрямами діяльності охоплює авіаційну, суднобудівну, оборонну галузі та галузь, що об'єднує радіоелектроніку, засоби зв'язку, електротехніку та приладобудування.

Україна є світовим лідером у виробництві навігаційних приладів, головок самонаведення для ракет «земля - повітря», станцій радіотехнічного контролю, звукометричних систем артилерійської розвідки, складних систем управління, апаратури радіозв'язку, радіотехнічної і радіоелектронної боротьби, авіаційних і ракетних систем прицілювання. В Україні збереглася добре розвинена електронно-оптична галузь.

Для подальшого розвитку оборонної галузі України було розроблено та схвалено Стратегію розвитку оборонно-промислового комплексу України на період до 2028 р., відповідно до якої визначено головні стратегічні орієнтири розвитку галузі, а саме: систематичне та раціональне рефрормування оборонно-промислового комплексу у цілому; створення та запровадження ефрективного механізму взаємодії між замовниками та підприємствами оборонно-промислового комплексу України; підтримка технічного та технологічного розвитку підприємств обороннопромислового комплексу; інтеграція національних виробників на міжнародний ринок та підвищення їхніх експортних можливостей; поліпшення фрінансового стану підприємств оборонної галузі; покращення інвестиційного клімату для розвитку підприємств оборонної галузі.

Для реалізації поставлених стратегічних цілей підприємствам оборонної галузі України необхідно значну увагу приділити організації механізму управління маркетинговою діяльністю кожного підприємства, яке входить до складу оборонної галузі та забезпечує її діяльність.

Управління маркетинговою діяльністю підприємства слід розглядати як сукупність процесів, які включають у себе аналіз, планування, реалізацію та контроль над процесом реалізації заходів, які необхідні для встановлення, зміцнення і підтримки процесів обміну на цільових ринках для досягнення відповідної мети підприємства, а саме або отримання прибутку, або зростання обсягів збуту, або збільшення частки ринку, або проникнення на ринок, або створення тісних взаємозв'язків з учасниками системи зовнішньоекономічної діяльності. Така система заходів обов'язково містить у собі маркетингову товарну політику, цінову політику, політику розподілу та комунікаційну політику.

Механізм управління маркетинговою діяльністю підприємства повинен включати в себе такі основні моменти: кількість і якість товару/ послуги; ресурси, необхідні для виробництва та реалізації товарів/послуг; технологія виробництва/

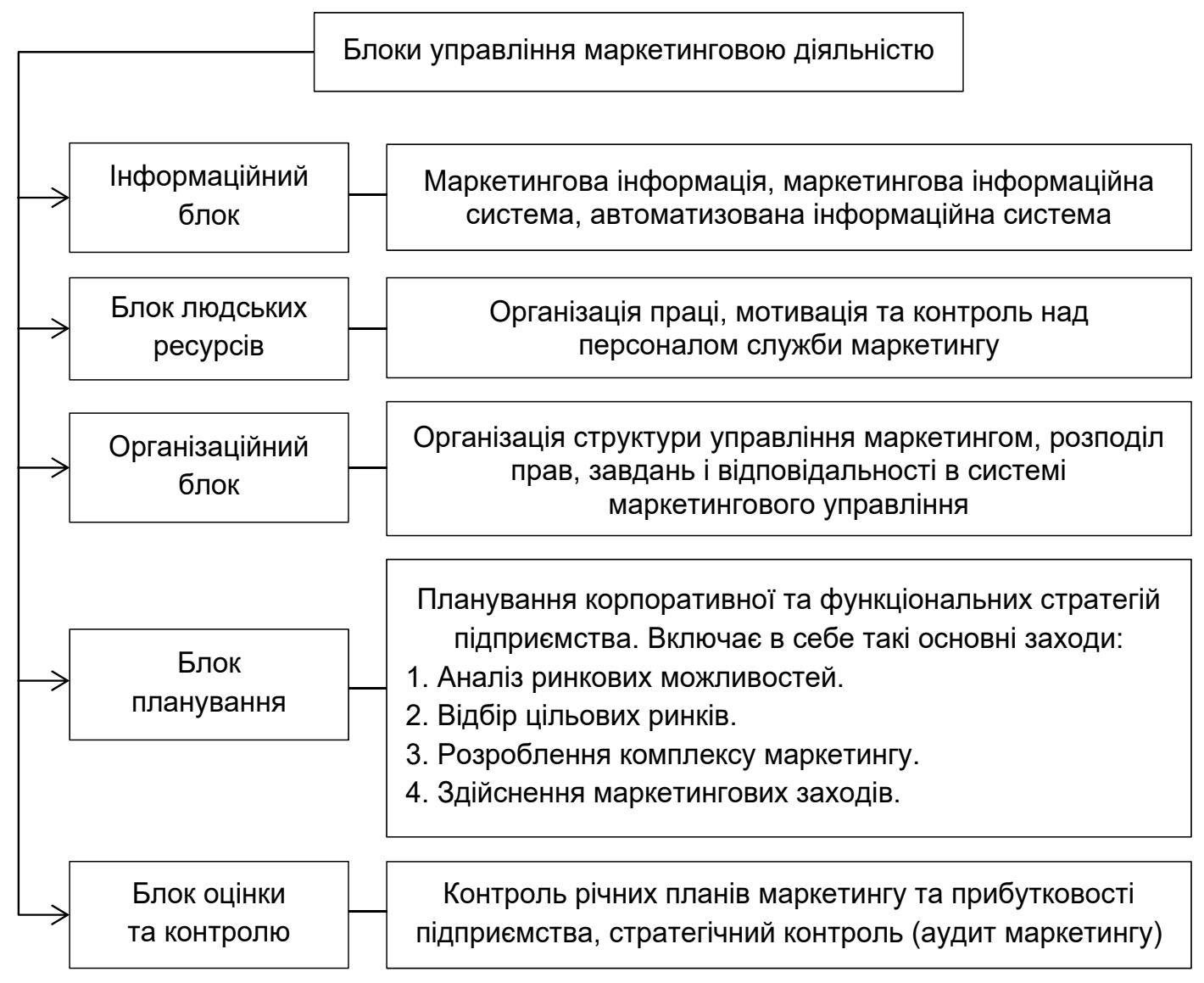

Рис. 1. Блоки управління маркетинговою діяльністю на підприємстві 
створення; система виконавців; терміни; місце; споживачі товарів/послуг; асортимент, упаковка, ціна, продаж і реклама.

Для реалізації основних напрямів діяльності підприємства механізм управління маркетинговою діяльністю на підприємстві повинен складатися 3 п'яти основних блоків, які представлені на рис. 1.

Наведені блоки управління маркетинговою діяльністю забезпечують виконання основних фрункцій маркетингу, які необхідні для реалізації фрункцій управління.

Функціональне забезпечення механізму управління маркетинговою діяльністю підприємства можна відобразити на основі відповідної моделі фрункціонування такої системи управління. У цілому модель управління маркетинговою діяльністю складається 3 таких елементів, як функціональне забезпечення маркетингової діяльності, дослідження ринку, розроблення комплексу маркетингу. У широкому фрорматі модель управління маркетинговою діяльністю підприємства представлено на рис. 2.

Контроль результативності та оцінка ефективності реалізації механізму управління марке- тинговою діяльністю підприємства - це необхідний крок до розуміння доцільності використання вибраного напряму маркетингової діяльності підприємства, який допомагає виявити недоліки та усунути їх. Аналіз еоективності представленого вище механізму управління маркетинговою діяльністю було проведено на базі Державного підприємства «Конотопський авіаремонтний завод «Авіакон».

Державне підприємство «Конотопський авіаремонтний завод «Авіакон» засноване у 1931 р. як авіаційні майстерні у складі 18-го авіапарку 18-ї авіабригади УВО, які виконували ремонт літаків ТБ-3, P-6, І-16, ДБ-3А, ДБ-ЗФ і авіадвигунів М-5, М-17, М-87, М-88. 32011 р. підприємство входить до складу ДК «Укроборонпром».

Основними сорерами діяльності підприємства оборонної галузі є:

- капітально-відновлювальний ремонт, переобладнання та модернізація вертольотів Мі-6, Мі-2, Мі-8, Мі-17, Мі-24, Мi-35 і Мі-26 усіх модифікацій та їх обладнання;

- дослідження технічного стану вертольотів у місцях їх експлуатації;

$$
\begin{aligned}
& \begin{array}{|c|}
\text { Елементи розширеної моделі управління маркетинговою } \\
\text { діяльністю підприємства }
\end{array} \\
& \text { Дослідження ринку з метою виявлення загроз і можливостей для } \\
& \text { підприємства }
\end{aligned}
$$

Рис. 2. Розширена модель управління маркетинговою діяльністю 
- експлуатаційна підтримка відремонтованих вертольотів;

- підготовка та підвищення кваліфікації фрахівців замовників.

Комплекс маркетингу підприємства $є$ основою всієї системи маркетингу, а управління комплексом маркетингу стає головним завданням досягнення успішності на ринку. Комплекс маркетингу авіаремонтного заводу представлено в табл. 1.

Товарна політика відіграє важливу роль у здійсненні комерційної і маркетингової діяльності підприємства на ринку. Маркетинговим аспектом є дії, спрямовані на забезпечення споживачів товарами та послугами, а комерційний аспект - це досягнення економічної едрективності діяльності підприємства у здійсненні закупок і збуті продукції. Таким чином, для реалізації ефрективної системи маркетингового управління необхідно передусім звернути увагу на товарний асортимент підприємства (табл. 2).

Дані табл. 2 свідчать, що підприємство у своєму асортименті має три головні позиції з реалізації товарів та надання послуг. Ширина асортименту товари, послуги 3 ремонту та обслуговування та інші послуги. Глибина асортименту: товари - 8; послуги 3 ремонту та обслуговування - 8, інші послуги - 7; насиченість - 23 одиниці.

Наступним кроком в аналізі маркетингової діяльності авіаремонтного заводу є дослідження показників збутової діяльності (табл. 3).

Дані табл. 3 свідчать, що показник співвідношення фрінансового результату від операційної діяльності та доходу (виручки) від реалізації продукції у 2019 р. порівняно з 2017 р. зменшився на 0,13, або на 41,87 п.в., а показник співвідношення чистого прибутку та доходу (виручки) від реалізації продукції зменшився на 0,11, або на 32,43 п.в. Причиною цього стало зменшення показників фрінансового результату від операційної діяльності на 115341,00 тис грн, або на 29,36 п.в., чистого прибутку - на 94 452,00 тис грн, або на 22,74 п. в. та доходу від реалізації продукції - на 220 207,00 тис грн, або на 70,13 п. в. Дана тенденція $€$ негативною для діяльності підприємства.

Ефективність роботи та ефективність маркетингової діяльності підприємства, яке входить до складу ДК «Укроборонпром», відображаються в обсягах укладених договорів у системі Prozorro.

Кількість укладених договорів авіаремонтним заводом у системі Prozorro представлено на рис. 3 .

Дані рис. 3 свідчать, що починаючи з 2016 р. авіаремонтний завод уклав 108 договорів, серед яких - 67 договорів, або 62,0\%, виконано, 2 договори, або 1,9\%, розірвано та 39 договорів, або 36,1\%, - активні.

Аналіз показників ефективності роботи підприємства у сорері державних закупівель представлено в табл. 4.

Дані табл. 4 свідчать, що починаючи 3 2016 р. авіаремонтний завод розмістив на платфрормі Prozorro 124 лоти-пропозиції на загальну вартість 214 652,4 тис грн. Відсоток неконкурентних лотів, що пропонував завод, становить 100,0\%,

Таблиця 1

Елементи комплексу маркетингу

Державного підприємства «Конотопський авіаремонтний завод «Авіакон»

\begin{tabular}{|c|c|c|c|}
\hline Товар / Послуга, од. & $\begin{array}{c}\text { Ціна, } \\
\text { тис грн / од. }\end{array}$ & Розподіл & Стимулювання \\
\hline $\begin{array}{l}\text { Послуги з ремонту, технічного обслуговування повітряного, } \\
\text { залізничного, морського транспорту і пов'язаного обладнання } \\
\text { та дорожньої інфрраструктури, а також супутні послуги }\end{array}$ & 160000,0 & \multirow{14}{*}{$\begin{array}{c}\text { Метод збуту - } \\
\text { за допомогою } \\
\text { платорорми } \\
\text { Рrozorro } 3 \\
\text { використанням } \\
\text { системи } \\
\text { договорів на } \\
\text { постачання } \\
\text { послуг. } \\
\text { Отримання } \\
\text { державних } \\
\text { замовлень. } \\
\text { Система збуту - } \\
\text { традиційна } \\
\text { (усі учасники } \\
\text { незалежні один } \\
\text { від одного) }\end{array}$} & \multirow{14}{*}{$\begin{array}{c}\text { Участь у } \\
\text { виставках, } \\
\text { ярмарках. } \\
\text { Розміщення } \\
\text { інфрормації } \\
\text { про діяльність } \\
\text { та власному } \\
\text { вебсайті. } \\
\text { Інорормування } \\
\text { учасників } \\
\text { державних } \\
\text { закупівель } \\
\text { через систему } \\
\text { Рrozorro }\end{array}$} \\
\hline Зброя, боєприпаси та супутні деталі & 43000,0 & & \\
\hline $\begin{array}{l}\text { Частини повітряних і космічних літальних апаратів та } \\
\text { вертольотів }\end{array}$ & 700,0 & & \\
\hline Металеві троси & 230,0 & & \\
\hline Гумові вироби & 190,0 & & \\
\hline $\begin{array}{l}\text { Послуги з ремонту і технічного обслуговування насосів, } \\
\text { клапанів, кранів і металевих контейнерів }\end{array}$ & 99,0 & & \\
\hline Дослідницькі послуги & 98,0 & & \\
\hline $\begin{array}{l}\text { Послуги з ремонту і технічного обслуговування транспортних } \\
\text { засобів військового призначення }\end{array}$ & 96,0 & & \\
\hline $\begin{array}{l}\text { Послуги з ремонту і технічного обслуговування } \\
\text { вимірювальних, випробувальних і контрольних приладів }\end{array}$ & 86,0 & & \\
\hline Обладнання для повітряних літальних апаратів & 74,0 & & \\
\hline $\begin{array}{l}\text { Послуги з ремонту і технічного обслуговування військових } \\
\text { літаків, ракет і космічних апаратів }\end{array}$ & 58,0 & & \\
\hline $\begin{array}{l}\text { Послуги з ремонту і технічного обслуговування військових } \\
\text { електронних систем }\end{array}$ & 46,0 & & \\
\hline Послуги з обслуговування літальних апаратів & 11,0 & & \\
\hline Послуги з ремонту і технічного обслуговування техніки & 2,7 & & \\
\hline
\end{tabular}


Склад товарної пропозиції

\begin{tabular}{|c|c|}
\hline $\begin{array}{c}\text { Групи товарів/ } \\
\text { послуг }\end{array}$ & Підгрупи \\
\hline \multirow{8}{*}{ 1. Товари } & 1.1. Кріпильні деталі \\
\hline & 1.2. Двигуни та їх частини \\
\hline & 1.3. Зброя, боєприпаси та супутні деталі \\
\hline & 1.4. Пара, гаряча вода та пов'язана продукція \\
\hline & 1.5. Частини повітряних і космічних літальних апаратів та вертольотів \\
\hline & 1.6. Металеві троси \\
\hline & 1.7. Контрольно-вимірювальне обладнання \\
\hline & 1.8. Гумові вироби \\
\hline \multirow{8}{*}{$\begin{array}{l}\text { 2. Послуги } 3 \\
\text { ремонту та } \\
\text { обслуговування }\end{array}$} & $\begin{array}{l}\text { 2.1. Послуги з ремонту, технічного обслуговування повітряного, залізничного, морського } \\
\text { транспорту і пов'язаного обладнання та дорожньої інфрраструктури, а також супутні послуги }\end{array}$ \\
\hline & $\begin{array}{l}\text { 2.2. Послуги з ремонту і технічного обслуговування насосів, клапанів, кранів і металевих } \\
\text { контейнерів }\end{array}$ \\
\hline & 2.3. Послуги з ремонту і технічного обслуговування транспортних засобів військового призначення \\
\hline & $\begin{array}{l}\text { 2.4. Послуги з ремонту і технічного обслуговування вимірювальних, випробувальних і } \\
\text { контрольних приладів }\end{array}$ \\
\hline & 2.5. Послуги з ремонту і технічного обслуговування військових літаків, ракет і космічних апаратів \\
\hline & 2.6. Послуги з ремонту і технічного обслуговування військових електронних систем \\
\hline & 2.7. Послуги з обслуговування літальних апаратів \\
\hline & 2.8. Послуги з ремонту і технічного обслуговування техніки \\
\hline \multirow{6}{*}{ 3. Інші послуги } & 3.1. Випробування та оцінювання \\
\hline & 3.2. Дослідницькі послуги \\
\hline & 3.3. Послуги з автомобільних перевезень \\
\hline & 3.4. Послуги зберігання та складування \\
\hline & 3.5. Обладнання для повітряних літальних апаратів \\
\hline & 3.6. Фарбування та скління \\
\hline
\end{tabular}

Збутова діяльність у фрормуванні фрінансових результатів Державного підприємства «Конотопський авіаремонтний завод «Авіакон»

\begin{tabular}{|c|c|c|c|c|c|}
\hline \multirow{2}{*}{ Показники } & \multirow{2}{*}{2017 p. } & \multirow{2}{*}{2018 p. } & \multirow{2}{*}{2019 p. } & \multicolumn{2}{|c|}{ Відхилення 2019 р. до 2017 р. } \\
\hline & & & & $+1-$ & $\%$ \\
\hline Дохід від реалізації продукції, тис грн & 737114,00 & 722043,00 & 516907,00 & $-220207,00$ & 70,13 \\
\hline Собівартість реалізованої продукції, тис грн & 421978,00 & 377998,00 & 295047,00 & $-126931,00$ & 69,92 \\
\hline Адміністративні витрати, тис грн & 40181,00 & 54203,00 & 73614,00 & 33433,00 & 183,21 \\
\hline Витрати на збут, тис грн & 60588,00 & 140724,00 & 67379,00 & 6791,00 & 111,21 \\
\hline Інші операційні витрати, тис грн & 99484,00 & 154900,00 & 143257,00 & 43773,00 & 144,00 \\
\hline $\begin{array}{l}\text { Разом витрат, пов'язаних з операційною } \\
\text { діяльністю, тис грн }\end{array}$ & 200253,00 & 349827,00 & 284250,00 & 83997,00 & 141,95 \\
\hline $\begin{array}{l}\text { Частка витрат на збут у витратах, } \\
\text { пов'язаних з операційною діяльністю, \% }\end{array}$ & 30,26 & 40,23 & 23,70 & $-6,55$ & 78,35 \\
\hline $\begin{array}{l}\text { Окупність витрат на збут (дохід до витрат } \\
\text { на збут), тис грн }\end{array}$ & 12,17 & 5,13 & 7,67 & $-4,49$ & 63,06 \\
\hline $\begin{array}{l}\text { Фінансовий результат від операційної } \\
\text { діяльності, тис грн }\end{array}$ & 163291,00 & 79139,00 & 47950,00 & $-115341,00$ & 29,36 \\
\hline $\begin{array}{l}\text { Фінансовий результат від операційної } \\
\text { діяльності на } 1 \text { грн витрат на збут }\end{array}$ & 2,70 & 0,56 & 0,71 & $-1,98$ & 26,41 \\
\hline
\end{tabular}

Показники ефективності роботи Державного підприємства «Конотопський авіаремонтний завод «Авіакон» на платформі Prozorro

\begin{tabular}{|l|c|}
\hline \multicolumn{1}{|c|}{ Показники } & Обсяг \\
\hline Очікувана вартість, тис грн & 39930,6 \\
\hline Кількість лотів & 124 \\
\hline$\%$ неконкурентних лотів (сума/к-ть) & $100,0 / 100,0$ \\
\hline$\%$ лотів за договорами (сума/к-ть) & $54,7 / 87,1$ \\
\hline Вартість договорів, тис грн & 214652,4 \\
\hline Кількість договорів & 108 \\
\hline
\end{tabular}




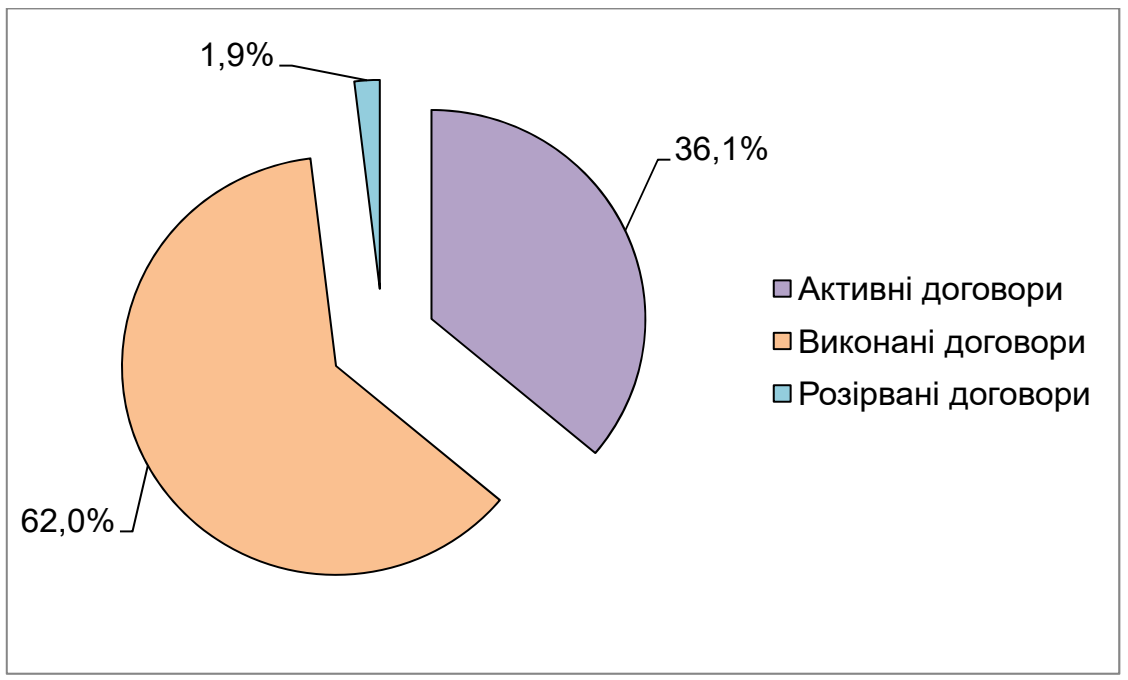

Рис. 3. Кількість договорів, що укладені Державним підприємством «Конотопський авіаремонтний завод «Авіакон» на платформі Prozorro

що свідчить, що завод надає унікальні послуги і реалізує товари, що не мають аналогів. Відсоток лотів за договорами становить 54,7\%. Обсяг виконаних договорів - 99,5\%.

Дані показники є позитивними, але обсяг діяльності авіаремонтного заводу на платорормі закупівель Prozorro $€$ недостатньо великим. Причиною цього є специфріка діяльності даного підприємства.

Таким чином, маркетингова діяльність Державного підприємства «Конотопський авіаремонтний завод «Авіакон» проводиться ефективно, 3 правильним використанням механізму управління його маркетинговою діяльністю.

Висновки 3 проведеного дослідження. Управління маркетинговою діяльністю підприємства та механізм його реалізації повинні бути спрямовані на ефективність реалізації напрямів діяльності підприємства і забезпечувати своєчасне виявлення та зниження або подолання маркетингових ризиків, чітке визначення цілей маркетингової діяльності та діяльності підприємства, вірне планування всіх заходів маркетингової діяльності, провадити ефективний контроль процесу управління маркетинговою діяльністю та здійснювати своєчасне оперативне втручання у маркетингові процеси під впливом змін чинників внутрішнього та зовнішнього маркетингового середовища.

\section{БІБЛІОГРАФІЧНИЙ СПИСОК:}

1. Жегус О.В. Маркетингові інновації як необхідна умова розвитку підприємства. Економічна стратегія і перспективи розвитку сорери торгівлі та послуг. 2015. Вип. 2. С. 227-238.

2. Маказан Є.В. Сучасні маркетингові принципи управління підприємством. Вісник Приазовського державного технічного університету. 2019. Вип. 31. T. 2. C. $49-54$.
3. Ооріційний сайт Державного підприємства «Конотопський авіаремонтний завод «Авіакон». URL: http://www.aviakon.com (дата звернення: 22.01.2021).

4. Райко Д.В. Модель управління маркетингом у системі менеджменту промислового підприємства. Маркетинг і менеджмент інновацій. 2015. № 1 C. $107-123$.

5. Стратегія розвитку оборонно-промислового комплексу України на період до 2028 року. URL: https://zakon.rada.gov.ua/laws/show/442-2018-p\#Text (дата звернення: 15.12.2020).

\section{REFERENCES:}

1. Zhehus O.V. (2015) Marketynhovi innovatsii yak neobkhidna umova rozvytku pidpryiemstva [Marketing innovations as a necessary condition for enterprise development]. Ekonomichna stratehiia i perspektyvy rozvytku sfery torhivli ta posluh, vol. 2, pp. 227-238.

2. Makazan Ye.V. (2019) Suchasni marketynhovi pryntsypy upravlinnia pidpryiemstvom [Modern marketing principles of enterprise management]. Visnyk Pryazovskoho derzhavnoho tekhnichnoho universytetu, vol. 31 (2), pp. 49-54.

3. Ofitsiinyi sait Derzhavnoho pidpryiemstva «Konotopskyi aviaremontnyi zavod «Aviakon» [Official site of the State Enterprise «Konotop Aircraft Repair Plant «Aviacon»]. Available at: http://www.aviakon.com (accessed 22 January 2021).

4. Raiko D.V. (2015) Model upravlinnia marketynhom u systemi menedzhmentu promyslovoho pidpryiemstva [Marketing management model in the management system of an industrial enterprise]. Marketynh i menedzhment innovatsii, vol. 1, pp. 107-123.

5. Stratehiia rozvytku oboronno-promyslovoho kompleksu Ukrainy na period do 2028 roku [Strategy for the development of the defense-industrial complex of Ukraine for the period up to 2028]. Available at: https://zakon.rada.gov.ua/laws/show/442-2018-r\#Text (accessed 12 December 2020). 